\title{
CHANGES IN LABOUR FORCE EXTERNAL MOBILITY MODEL FOR ROMANIANS. MAIN RESTRICTIONS AND CHALLENGES
}

\author{
Valentina Vasile ${ }^{1}$ \\ Mariana Bălan ${ }^{2}$
}

\begin{abstract}
The strongest determination of external labour mobility is given by the economic development level from the country of destination and the superior equivalent income that might be obtained by wage employment or entrepreneurship, as compared with the country of origin. Labour immigrants represent the overwhelming share of immigrants (OECD, 2008). For less developed countries, labour migration generates potential losses that cannot be substituted by remittances or other "soft" advantages which pertain to the labour market due to the increasingly longer period of temporary migration.

In the present paper we highlight the shifts in size and intensity of labour mobility flows for Romanians in the last decade. It is underpinned that the highest mobility propensity was registered among youths who, paradoxically to the economic growth context couldn't find adequate jobs in the country and accepted employment abroad - under conditions of underemployment, overqualification and sometimes even in other fields of activity than the professional training profile. The first 5 countries of destination change the hierarchy in the Romanians' preferences. This change of destinations signifies also a change of the structure according to educational level and profile, decreasing the share of those with tertiary training, but not also the absolute number which is increasing. Quantitatively, we lose more high-skilled youths.
\end{abstract}

Key words: labour force mobility, immigrant jobs, high skilled youth

JEL Codes: M5

\section{Introduction}

Currently, labour force mobility although declared as universal acknowledged right is realised either directly or indirectly based on the selective policies of host countries for covering the qualitative and numerical deficit of the labour force. The immigrant population is relatively younger and better trained, yet only to a small extent generates the replacement of the autochthonous labour force, as generally it completes vacancies not employed with autochthones (because these jobs are refused by them for considerations of too small incomes, low-skilled or "shameful" jobs) or those jobs based on contracts and/or contingents, respectively which are at the express demand of employers.

Labour immigrants represent the overwhelming share of immigrants, the population categories "youths and elderly" representing together around 1/4 from total ${ }^{3}$ (OECD, 2008). A synthesis of socio-economic particularities for immigrants as compared with the autochthonous labour force highlights the comparative advantage of potential labour force entering into countries of destination:

\footnotetext{
${ }^{1}$ Institute of National Economy-Romanian Academy, Bucharest, Romania, e-mail: valentinavasile2009@gmail.com

${ }^{2}$ Institute of National Economy-Romanian Academy, Bucharest, Romania, e-mail: dr.mariana.balan@gmail.com

${ }^{3}$ The 15 to 24 year old foreign born population represents $13.2 \%$ and those over 65 years of age represent $13.9 \%$, as average for OECD countries while the equivalent autochthonous population represents 17.9 , respectively $17.1 \%$. în timp ce populația autonomă echivalentă reprezintă 17,9 şi respectiv, 17,1\%
} 
Table no. 1.

Comparative advantages and disadvantages of the foreign labour force against the autochthonous one in OECD countries

\begin{tabular}{|c|c|c|}
\hline Advantage/disadvantage & Foreign labour force & $\begin{array}{c}\text { Autochthonous labour } \\
\text { force }\end{array}$ \\
\hline $\begin{array}{l}\text { Their share in total } \\
\text { population in the country of } \\
\text { destination is relatively low } \\
\text { with high differences on } \\
\text { countries }\end{array}$ & $\begin{array}{l}9 \% \text { of those over } 15 \text { years of age and over } \\
\text { ( } 7.5 \% \text { from total population). The highest } \\
\text { share is in Luxembourg of } 32.6 \%\end{array}$ & $\begin{array}{l}\text { Covers the demographic } \\
\text { deficits due to ageing }\end{array}$ \\
\hline $\begin{array}{l}\text { Women share increases } \\
\text { relatively }\end{array}$ & $\begin{array}{l}\text { The share of women is by } 51 \% \text { higher in } \\
\text { countries providing specific jobs in } \\
\text { households and long-term care services }\end{array}$ & $\begin{array}{l}\text { Unattractive and poorly } \\
\text { remunerated jobs refused } \\
\text { by autochthones (the "3D } \\
\text { jobs"). }\end{array}$ \\
\hline Younger & $\begin{array}{l}\text { Covers the younger age groups of the } \\
\text { segment } 25 \text { to } 64 \text { years of age - labour } \\
\text { demand is addressed with predilection to } \\
\text { the contingent up to } 35 \text { to } 40 \text { years of age. }\end{array}$ & $\begin{array}{l}\text { Diminishment } \\
\text { demographic effects. }\end{array}$ \\
\hline $\begin{array}{l}\text { More skilled \& more poorly } \\
\text { educated }\end{array}$ & $\begin{array}{l}\text { The share of those with tertiary education } \\
\text { is of } 23.6 \% \text {. The share of those with lower } \\
\text { education is higher than in the case of the } \\
\text { natives (the distribution curve follows the } \\
\text { shape of the letter U). }\end{array}$ & $\begin{array}{l}\text { The share of those with } \\
\text { tertiary education is of } \\
19.1 \% \text { ' they are fewer than } \\
\text { the low-skilled ones }\end{array}$ \\
\hline Unemployment rate & $\begin{array}{l}\text { Higher: the employment of those aged } 15 \\
\text { to } 64 \text { years of age is in average of } 62.3 \% \text {. } \\
\text { Differences on countries with respect to } \\
\text { performances on labour market, lower for } \\
\text { the more recent migrants (around 2000) }\end{array}$ & \begin{tabular}{llr}
\multicolumn{2}{|l}{ Employment $66 \%$} & with \\
lower differences & for \\
women & & \\
\end{tabular} \\
\hline $\begin{array}{l}\text { The distribution on } \\
\text { activities after the training } \\
\text { level required on the job is } \\
\text { asymmetric }\end{array}$ & $\begin{array}{l}\text { Higher in low-skill services: agriculture } \\
\text { and industry } 28.2 \%, 12.4 \% \text { in productive } \\
\text { services, } 20 \% \text { in distribution services and } \\
39.3 \% \text { in social and personal services } \\
\text { (including education and health) }\end{array}$ & $\begin{array}{l}\text { Higher in services/high- } \\
\text { skilled activities: } \\
\text { agriculture and industry } \\
33 \%, 10.6 \% \text { in productive } \\
\text { services, } 21 \% \text { in } \\
\text { distribution services }\end{array}$ \\
\hline $\begin{array}{l}\text { Geographic concentration } \\
\text { depending on the proximity } \\
\text { of the country of } \\
\text { destination }\end{array}$ & Bilateral labour mobility $^{4}$ & $\begin{array}{l}\text { Most attractive areas: USA, } \\
\text { Germany, France, Canada } \\
\text { and the United Kingdom }\end{array}$ \\
\hline
\end{tabular}

As result, the inflow of migrants represents a factor of rebalancing the labour market and additional potential of economic growth, a potential lost by the countries of origin and which is not compensated but partially by remittances sent in the country. The comparative advantages gained by the country of destination are amplified on medium- and long-term which justified and otherwise motivated naturalisation decisions of immigrants, in particular of the highly-skilled ones (Vasile, V., Vasile, L., 2011).

In the last decade, the new immigrants contributed by over $70 \%$ from employment increase on the European labour market and by $47 \%$ in the USA, thus being highlighted the increasing role of maintaining and rising employment in many developed countries that are facing demographic ageing and structural deficit of competences and skills.

\footnotetext{
${ }^{4}$ About $60 \%$ from the foreign born population in the OECD European countries originate from other European countries (28\% from EU15, 5.4\% from EU10 and 24.7\% from other countries of Europe, including Turkey). OECD 2008 .
} 


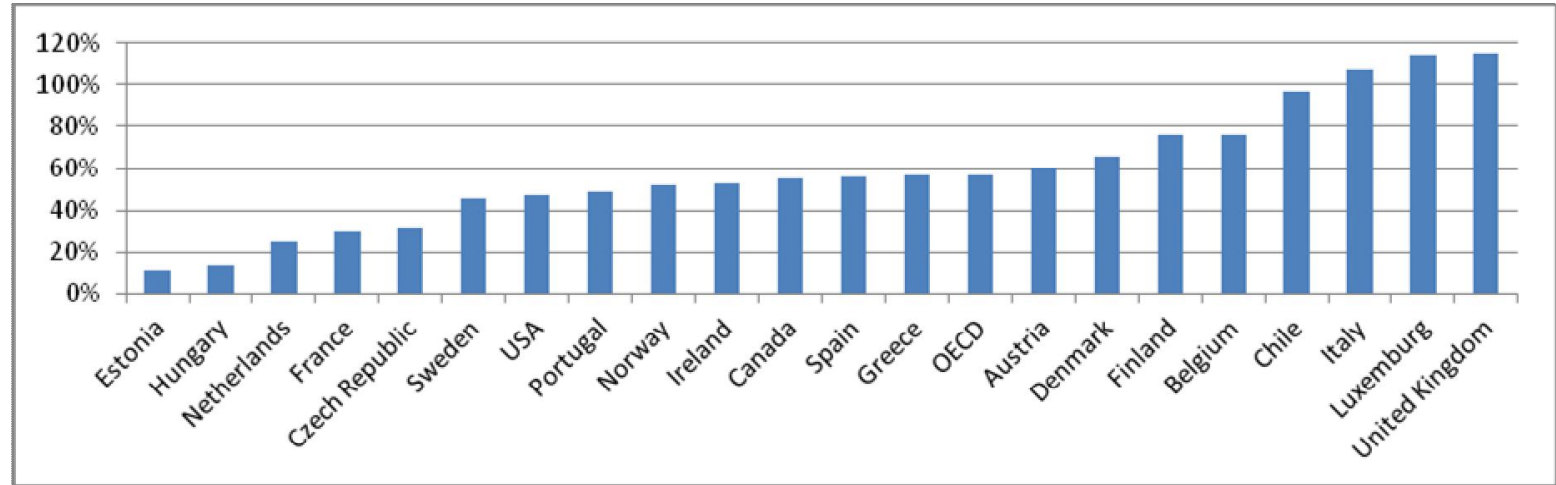

Source: OECD International migration Outlook 2012, www.oecd.org/migration/imo

Graph no.1. - Contribution of international migration to increasing labour force in some OECD countries in the period 2000-2010

In the past decade, in the period up to the crisis, mobility flows for labour increased significantly, especially in some countries from southern Europe and Ireland. In the first half of the years 2000, the increases of migrant population for labour were realised through:

a) increase in the number of the countries of origin and change of flows' intensity on countries of destination, the increases of labour force flows within the EU area due to the $10+2$ new member countries (flows from the pre- and post-accession period);

b) higher average educational level of migrants and of the youths contingents with tertiary education;

c) the increase in the labour force share aged 25 to 49 years of age and in some instances, in particular towards the end of the last decade, the increase in the share of individually and more educated migrant women;

d) the change in the structure of migrant population on professions and training levels, as result of the special immigration policies promoted by the destination countries.

As result of the above-mentioned factors and in particular of the limiting and specialisation policy of immigration in some EU countries, the migration dynamics and profile changed, adjusting more on covering employment deficits from countries of destination and generated a polarisation of migrant labour force structure (new migrants) at the extremes of the occupations' and professions' spectrum. Because the expectations of the migrants exceeded the demands and employment conditions of the local markets from the countries of destination, over-specialisation and underemployment turned into the predominant characteristic of the immigrants' labour market. Also, the medium- and high-skilled population flows from medium developed countries have been more intense, even under conditions of economic growth (the Romanian case).

At the level of the new EU member states, the increase of migrant population was of 33\% for Poland (about 70 thousand persons), for the Czech Republic and Slovakia 12\% (79 thousand persons), $88 \%$ for Romania (740 thousand persons) and doubled for Bulgaria (180 thousand persons, $+119 \%$ ) (DIOC data 2005/6, Widmaier, S. and Dumont, J.-C., 2011) 
Table no. 2

Characteristics of the migrant population from EU-27

\begin{tabular}{|l|l|l|l|}
\hline EU 27 & $\mathbf{2 0 0 0}$ & $\mathbf{2 0 0 5 / 6}$ & Differences 2005/6 against 2000 \\
\hline $\begin{array}{l}\text { Migrant population aged 15 } \\
\text { years and over (thousand } \\
\text { persons) }\end{array}$ & 19370 & 22096 & +2726 persons $(+14,1 \%)$ \\
\hline Women share (\%) & 53,2 & 52,7 & $\begin{array}{l}-0.5 \mathrm{pp} \text { with high differences on countries in } \\
\text { both senses }\end{array}$ \\
\hline Youths 15-24 years of age (\%) & 7,5 & 8,3 & $+0.8 \mathrm{pp}$ \\
\hline Persons aged 25-64 years (\%) & 69.4 & 69,0 & $\begin{array}{l}-0.4 \mathrm{pp} \text { with high differences on countries in } \\
\text { both senses, due to the age group 15 to 24 years } \\
\text { of age }\end{array}$ \\
\hline Recent migrants (\%) & 10.0 & 16.5 & \begin{tabular}{l}
$+6.5 \mathrm{pp}$ \\
\hline
\end{tabular}
\end{tabular}

Source: OCDE database DIOC 2005/06.

If we would analyse the situation of migration from Romania, as compared with the flows from other countries considering only those destinations significant also for the labour markets from the host country (for countries where Romania is counted among the first 5 countries of origin), a clear influence is found for the bilateral policies from the period when free movement was limited pre-accession. DIOC data 2005/6 highlight two broad trends:

- on one hand, mobility moderation as a continuation of the immigration policy from the last two decades, and this is the case for developed countries (such as Germany) and in the last decade Greece, and

- on the other hand, openness and significant contingents admission by yearly agreements of the countries of destination with Romania (through the Ministry of Labour), such as the case of Spain, or in the one of accessibility based on labour permits (the case of Italy).

The characteristic of these partial openness policies of the markets was the one of temporary employment supply, on short periods of time or seasonal work, which "stimulated" also the development of unregistered immigrant labour (remaining in the country of destination after termination of the labour contract or continuing labour relations but in the informal employment system). As result, social networks already shaped in the first migration decade are strengthened, new immigrant population from Romania concentrations emerge in certain areas from Spain, Italy, and Greece, and social support systems are developed for the temporary laid-off ones, reemployment is facilitated, including in the informal economy, etc.

\section{General features and particularities for Romanian labour force'mobility in the first part of the past decade}

At the level of the year 2000, the share of Romanians within EU member countries in total foreign born population was of $1.6 \%$, lower than of Indians (1.8\%), and higher than the one from Tunisia (1.3\%) [(DEV/DOC (2006)04, p. 60]. Romanians represented $1.4 \%$ of total highly-skilled foreigners and $1.3 \%$ of the low-skilled ones.

In Denmark, Finland, France, the United Kingdom and Netherlands, the share of Romanian migrants is low, and in turn Hungary, Slovakia, Austria and the Czech Republic hold the first 4 positions in the hierarchy of foreign citizens. Save for Hungary, where due to the proximity and presence of Hungarian ethnics in Romania the share of foreigners from Romania in Hungary is of about $49 \%$ from total foreigners, in all other countries of destination the foreigners originating from Romania do not exceed 4\% from total. Even in Germany known for old links and tradition in mobility to this country, Romanians do not exceed 1\%. In Spain and Greece, their presence varies around 2.5\% (2.4\% in Greece and 2.8\% in Spain), similar to Czech R. and Slovakia (2.7\%). In 
Austria, Italy and Sweden around the year 2000 were more high-skilled Romanians than unskilled ones, and in Luxembourg, Belgium, Germany and Sweden high-skilled Romanians held positions in the hierarchy of their share in total category better than the ones of low-skilled ones. It should be mentioned that between highly-skilled foreigners from Austria, Romanian are most numerous (rank 1 in hierarchy with $3.9 \%$ from total), the first place which is also held in Hungary with $41.7 \%$.

Table no. 3

\section{Share of citizens born in Romania living in EU countries and place held among} the first 12 countries of origin (2000)

\begin{tabular}{|c|c|c|c|c|c|c|c|c|c|}
\hline \multirow{2}{*}{$\begin{array}{c}\text { Host } \\
\text { country }\end{array}$} & \multicolumn{2}{|c|}{$\begin{array}{l}\text { Total foreign- } \\
\text { born }\end{array}$} & \multicolumn{2}{|c|}{$\begin{array}{c}\text { Total foreign- } \\
\text { born without the } \\
\text { nationality of the } \\
\text { host country }\end{array}$} & \multicolumn{2}{|c|}{$\begin{array}{l}\text { Low-skill } \\
\text { training }\end{array}$} & \multicolumn{2}{|c|}{ Highly-skilled } & \multirow{2}{*}{$\begin{array}{c}\text { Combined } \\
\text { hierarchy } \\
\text { (combined } \\
\text { hierarchic } \\
\text { ai score) }\end{array}$} \\
\hline & $\begin{array}{c}\text { Share in } \\
\text { total }\end{array}$ & $\begin{array}{l}\text { Position } \\
\text { in } \\
\text { hierarchy }\end{array}$ & $\begin{array}{c}\text { Share } \\
\text { in } \\
\text { total }\end{array}$ & $\begin{array}{c}\text { Position in } \\
\text { hierarchy }\end{array}$ & $\begin{array}{c}\text { Share } \\
\text { in } \\
\text { total }\end{array}$ & $\begin{array}{l}\text { Position } \\
\text { in } \\
\text { hierarchy }\end{array}$ & $\begin{array}{c}\text { Share } \\
\text { in } \\
\text { total }\end{array}$ & $\begin{array}{l}\text { Position } \\
\text { in } \\
\text { hierarchy }\end{array}$ & \\
\hline Austria & 3,9 & 4 & 2,7 & 5 & 3,1 & 5 & 3,9 & 1 & 15 \\
\hline Hungary & 49,1 & 1 & 39,4 & 1 & $\begin{array}{l}47, \\
2\end{array}$ & 1 & 41,7 & 1 & 4 \\
\hline Slovakia & 2,7 & 2 & 4,2 & 2 & 4,3 & 2 & 1,3 & 5 & 11 \\
\hline Italy & 3,9 & 4 & 6,0 & 3 & 2,4 & 8 & 3,0 & 5 & 20 \\
\hline $\begin{array}{l}\text { Luxem- } \\
\text { bourg }\end{array}$ & 0,5 & 9 & 0,4 & 10 & $\ldots$ & $>12$ & 0,7 & 7 & 39 \\
\hline Belgium & 0,7 & 11 & $\ldots$ & $>12$ & $\ldots$ & $>12$ & 1,3 & 7 & 44 \\
\hline Germany & 0,9 & 10 & $\ldots$ & $\ldots$ & 0,6 & 12 & 1,1 & 9 & 45 \\
\hline Greece & 2,4 & 7 & 3,1 & 4 & 1,9 & 8 & 2,2 & 11 & 30 \\
\hline Czech R. & 2,7 & 4 & 1,9 & 6 & 4,5 & 2 & 0,7 & 11 & 23 \\
\hline Poland & 0,5 & 9 & $\ldots$ & $>12$ & 0,6 & 9 & 0,4 & 12 & 43 \\
\hline Ireland & 1,5 & 5 & 2,3 & 4 & 1,3 & 3 & 0,8 & 12 & 24 \\
\hline Spain & 2,8 & 6 & 3,8 & 4 & 3,1 & 4 & 1,7 & 12 & 26 \\
\hline Sweden & $\ldots$ & $>12$ & $\ldots$ & $>12$ & $\ldots$ & $>12$ & 1,8 & 9 & 45 \\
\hline Portugal & $\ldots$ & $>12$ & 1,3 & 11 & $\ldots$ & $>12$ & $\ldots$ & $>12$ & 47 \\
\hline
\end{tabular}

Note: for the combined hierarchical score, for holding a higher position than 12 or lack of data (see Germany) because the exact position within the hierarchy is not known, the value of 13 was taken into account in all instances presented in the table

Source: processing after source: Katseli T.L., Lucas E.B. R., Xenogiani Th., 2006, Effects of migration on sending countries: what do we know?, OECD Development Centre Working Paper No. 250, DEV/DOC(2006)04, p 6369, based on OECD Database on Expatriates and Immigrants, 2004 (Census Data 1999-2003).

An image of Romanian immigrants within the EU area by the half of the past decade, when in Romania unfolded a period of intense economic growth, highlights the following aspects:

- For Germany, the demand of immigrants from Romania (a plus of about 100 thousand persons for the entire period) was centred on personnel with finalised studies, secondary education and preponderantly men, and by relatively maintaining their share in total immigrants of about 5\%; it should be mentioned that the share of young immigrants of up to 25 years of age - in their majority graduates - increases by about $2 \mathrm{pp}$.

- The flows to Greece were numerically relatively low (6 thousand persons) and increased the share of youths up to 25 years of age with secondary or low education, preponderantly men, who took low-skilled jobs from services and the household industry.

- Romanian immigrants from Italy turn into the second nationality as importance between foreigners on the labour market of this country, their number increasing by 147 thousand persons 
and their share to $7.9 \%$ from total (against $3.7 \%$ in 2000). As qualification structure, a sensible increase is registered for those with secondary training, over 25 years of age.

- Romania's bilateral agreements with Spain for low- and medium-skilled activities from agriculture and services have triggered the increase of the temporary employed labour force by about 350 thousand persons, with preponderantly medium skills and a significant increase in the share of women (strawberry-pickers). The youths maintain in relative terms their share in total migrants.

The first 3 migration destinations have absorbed a flow on increase, the share of those leaving to Germany, Spain and Italy increasing to about $70 \%$ from total (on increase by 9 pp). A slight decrease is seen for those placed at the educational extremes due to those with secondary training who preponderantly head to Spain, more numerous being women. The share of youths going to Germany increases and for the highly-skilled ones it increases to $16.6 \%$ in Spain, yet remains inferior as representativeness as compared with Germany (18.6\%).

Table no. 4.

Features of the migrant population from Romania to OECD countries, in the year 2000 and $2005 / 6$ on countries of destination (in countries where the stock of migrant population is among the first 5 countries of origin)

\begin{tabular}{|c|c|c|c|c|c|c|c|c|c|c|c|c|c|c|}
\hline \multirow{3}{*}{$\begin{array}{l}\text { Country of } \\
\text { destination } \\
\text { / } \\
\text { Country of } \\
\text { origin }\end{array}$} & \multicolumn{4}{|c|}{ Population } & \multicolumn{6}{|c|}{ Educational level } & \multicolumn{2}{|c|}{ Women } & \multicolumn{2}{|c|}{$\begin{array}{c}\text { Youths } \\
\text { 15-24 years } \\
\text { of age }\end{array}$} \\
\hline & \multicolumn{2}{|c|}{2000} & \multicolumn{2}{|c|}{$2005 / 06$} & \multicolumn{3}{|c|}{2000} & \multicolumn{3}{|c|}{$2005 / 06$} & \multirow{2}{*}{$\frac{2000}{\%}$} & \multirow{2}{*}{$\begin{array}{c}05 / 6 \\
\%\end{array}$} & \multirow{2}{*}{$\frac{2000}{\%}$} & \multirow{2}{*}{$\frac{05 / 6}{\%}$} \\
\hline & $\begin{array}{l}\text { Ths. } \\
\text { pers }\end{array}$ & $\%$ & $\begin{array}{l}\text { Ths. } \\
\text { pers }\end{array}$ & $\%$ & Low & $\begin{array}{l}\text { Secon- } \\
\text { dary }\end{array}$ & High & Low & $\begin{array}{l}\text { Secon- } \\
\text { dary }\end{array}$ & High & & & & \\
\hline \multicolumn{15}{|l|}{\begin{tabular}{|l|} 
GERMANY \\
\end{tabular}} \\
\hline Natives & 55099 & 87,5 & 61126 & 85,8 & 24,2 & 56,5 & 19,3 & 24,9 & 55,7 & \begin{tabular}{|l|}
19,4 \\
\end{tabular} & 51,8 & 51,6 & 13,3 & 13,9 \\
\hline $\begin{array}{l}\begin{array}{l}\text { Foreign } \\
\text { born }\end{array} \\
\end{array}$ & 7832 & 12,5 & 10076 & 14,2 & 45,8 & 39,3 & 14,9 & 44,0 & 40,4 & 15,6 & 49,7 & 50,3 & 11,7 & 12,4 \\
\hline Turkey & 1188 & 15,2 & 1569 & 15,6 & 74.8 & 21.6 & 3.6 & 71.6 & 23.9 & 4.5 & 47.7 & 48.1 & 6.7 & 8.9 \\
\hline \begin{tabular}{|l} 
Russian \\
Federation
\end{tabular} & 930 & 11.9 & 1403 & 13.9 & 39,8 & 43,1 & 17,1 & 39.7 & 43.5 & 16.8 & 53.0 & 53.3 & 18.5 & 19.0 \\
\hline Poland & 1027 & 13.1 & 1257 & 12.5 & 30.4 & 53.2 & 16.5 & 28.9 & 54.2 & 16.9 & 53,8 & 54.4 & 12.8 & 13.5 \\
\hline Kazakhstan & 372 & 4.8 & 646 & 6.4 & 35.7 & 49.1 & 15.3 & 40.5 & 48.0 & 11.5 & 52,0 & 51.7 & 14.9 & 19.5 \\
\hline Romania & 388 & 5.0 & 492 & 4.9 & 30.7 & 50.7 & 18.6 & 29.9 & 51.5 & \begin{tabular}{|l|}
18.6 \\
\end{tabular} & 53,7 & 54.9 & 9.0 & 10.9 \\
\hline \multicolumn{15}{|l|}{ GREECE } \\
\hline Natives & 8272 & 89.2 & 8442 & 88.7 & 52.5 & 33.5 & 14.0 & 50.2 & 34.3 & \begin{tabular}{|l|}
15.5 \\
\end{tabular} & 51.0 & 51.3 & 16.4 & 13.3 \\
\hline $\begin{array}{l}\begin{array}{l}\text { Foreign } \\
\text { born }\end{array} \\
\end{array}$ & 1000 & 10.8 & 1075 & 11.3 & 42.7 & 41.4 & 15.9 & 45.4 & 39.4 & 15.1 & 49.9 & 51.7 & 20.4 & 17.7 \\
\hline \begin{tabular}{|l|} 
Albania \\
\end{tabular} & 337 & 33.7 & 461 & 42.9 & 57.3 & 36. & 6. & 57.8 & 33.9 & 8. & 40.1 & 44.7 & 28.3 & 21.6 \\
\hline \begin{tabular}{|l} 
Russian \\
Federation
\end{tabular} & 66 & 6.6 & 96 & 8.9 & 47.5 & 35.5 & 17.0 & 46.0 & 35.8 & 18.2 & 58.9 & 59.3 & 15.0 & 17.6 \\
\hline Bulgaria & 36 & 3.6 & 47 & 4.4 & 49.0 & 38.1 & 12.9 & 46.5 & 42.7 & \begin{tabular}{|l|l|}
10.8 \\
\end{tabular} & 62.2 & 66.8 & 15.8 & 10.1 \\
\hline Germany & 91 & 9.1 & 43 & 4.0 & 22.4 & 53.3 & 24.3 & 21.2 & 48.6 & 30.2 & 54.4 & 59.5 & 18.5 & 11.1 \\
\hline Romania & 25 & 2.5 & 31 & 2.9 & 30.9 & 55.6 & 13.5 & 33.7 & 55.1 & \begin{tabular}{|l|l|}
11.1 \\
\end{tabular} & 22.7 & 15.8 & 47.7 & 52.7 \\
\hline \multicolumn{15}{|l|}{ ITALY } \\
\hline Natives & 46872 & 95.9 & 46974 & 94.4 & 63.6 & 28.3 & 8.1 & 58.6 & 32.4 & \begin{tabular}{|l|}
9.0 \\
\end{tabular} & 52.0 & 51.8 & 13.0 & 12.2 \\
\hline $\begin{array}{l}\text { Foreign } \\
\text { born }\end{array}$ & 2021 & 4.1 & 2813 & 5.6 & 54.3 & 33.5 & 12.2 & 50.4 & 38.5 & 11.2 & 54.4 & 53.7 & 13.9 & 13.1 \\
\hline Albania & 135 & 6.7 & 274 & 9.7 & 60.3 & 31.9 & 7.8 & 60.2 & 34.1 & \begin{tabular}{|l|}
5.7 \\
\end{tabular} & 42.9 & 46.2 & 24.1 & 22.4 \\
\hline Romania & 74 & 3.7 & 221 & 7.9 & 35.4 & 54.7 & 9.8 & 31.3 & 61.8 & \begin{tabular}{|l|}
6.9 \\
\end{tabular} & \begin{tabular}{|l|l|}
57.8 \\
\end{tabular} & 55.7 & 17.1 & 15.8 \\
\hline Morocco & 138 & 6.8 & 204 & 7.3 & 76.6 & 18.1 & 5.3 & 74.6 & 20.9 & 4.5 & 37.3 & 40.6 & 18.5 & 17.7 \\
\hline Switzerland & 180 & 8.9 & 187 & 6.7 & 47.9 & 44.0 & 8.2 & 38.5 & 51.9 & 9.6 & 54.0 & 52.7 & 12.4 & 8.6 \\
\hline Germany & 168 & 8.3 & 167 & 5.9 & 52.5 & 37.8 & 9.8 & 44.1 & 44.2 & 11.8 & 57.4 & 59.1 & 26.7 & 15.7 \\
\hline \multicolumn{15}{|l|}{\begin{tabular}{|l|} 
SPAIN \\
\end{tabular}} \\
\hline \begin{tabular}{|l} 
Natives \\
\end{tabular} & 32930 & 94.5 & 32886 & 88.5 & 66.4 & 15.6 & 18.0 & 61.4 & 17.5 & \begin{tabular}{|l|}
21.1 \\
\end{tabular} & 51.5 & 51.1 & 16.2 & 14.0 \\
\hline
\end{tabular}




\begin{tabular}{|l|l|l|l|l|l|l|l|l|l|l|l|l|l|l|}
\hline $\begin{array}{l}\text { Foreign } \\
\text { born }\end{array}$ & 1915 & 5.5 & 4255 & 11.5 & 56.3 & 22.6 & 21.1 & 45.5 & 30.9 & 23.6 & 49.7 & 50.8 & 16.8 & 16.1 \\
\hline Ecuador & 190 & 9.9 & 609 & 14.3 & 65.0 & 23,5 & 11,4 & 54.1 & 35.2 & 10.7 & 51,3 & 52,6 & 27,9 & 21,7 \\
\hline Morocco & 279 & 14.5 & 539 & 12.7 & 78.6 & 11.7 & 9.7 & 77.0 & 15.1 & 7.9 & 38,3 & 40.5 & 19,2 & 17.5 \\
\hline Romania & $\mathbf{5 1}$ & $\mathbf{2 . 7}$ & $\mathbf{3 9 5}$ & $\mathbf{9 . 3}$ & $\mathbf{6 2 . 3}$ & $\mathbf{2 4 . 8}$ & $\mathbf{1 3 . 0}$ & $\mathbf{3 8 . 3}$ & $\mathbf{4 5 . 1}$ & $\mathbf{1 6 . 6}$ & $\mathbf{4 0 . 8}$ & $\mathbf{4 9 . 2}$ & $\mathbf{2 3 , 1}$ & $\mathbf{2 3 . 3}$ \\
\hline Columbia & 144 & 7.5 & 322 & 7.6 & 53.8 & 28.6 & 17.6 & 38.2 & 42.6 & 19.2 & 59.7 & 59.8 & 21.8 & 16.9 \\
\hline Argentina & 93 & 4.8 & 270 & 6.3 & 40.3 & 27.4 & 32.3 & 33.1 & 31.9 & 35.0 & 51.3 & 49.3 & 15.2 & 14.4 \\
\hline
\end{tabular}

Source: Selection after Widmaier, S. and J-C. Dumont (2011), "Are recent immigrants different? A new profile of immigrants în the OECD based on DIOC 2005/06", OECD Social, Employment and Migration Working Papers No. 126, Directorate for Employment, Labour and Social Affairs, OECD Publishing, p. 53-55, http://dx.doi.org/10.1787/5kg3ml17nps4-en

What is important to mention is that the labour mobility flows have continued also in the period in which in Romania were registered the highest growth rates of GDP within the EU, when wages in the country of origin increased substantially, but without registering significant diminishments of the earnings differential as compared with the countries of destination.

The highest propensity for mobility was registered among youths who, paradoxically to the context of economic growth did not find adequate jobs in the country and accepted employment abroad - under conditions of under-employment, over-qualification and even in other fields of activity than the professional training profile.

Table no. 5 .

Change of flows' intensity and of the migrant population features from Romania towards the first three destinations in $2005 / 6$ as compared with 2000

\begin{tabular}{|c|c|c|c|c|c|c|c|c|c|c|c|c|}
\hline & \multicolumn{6}{|c|}{$2005 / 06$} & \multicolumn{6}{|c|}{ Change against the year 2000} \\
\hline & $\begin{array}{c}\text { Romanian } \\
\text { migrants } \\
\text { thousand } \\
\text { persons }\end{array}$ & $\%$ & $\begin{array}{c}\text { Low } \\
\text { education } \\
\text { (pp) }\end{array}$ & $\begin{array}{c}\text { Tertiary } \\
\text { education } \\
\text { (pp) }\end{array}$ & Women & $\begin{array}{c}\text { Youths } \\
15-24\end{array}$ & Number & $\begin{array}{c}\text { Structure } \\
\text { (pp) }\end{array}$ & $\begin{array}{l}\text { Low } \\
\text { educa } \\
\text { tion } \\
\text { (pp) }\end{array}$ & $\begin{array}{c}\text { Tertiary } \\
\text { educa } \\
\text { tion } \\
\text { (pp) }\end{array}$ & $\begin{array}{c}\text { Women } \\
\text { (pp) }\end{array}$ & \begin{tabular}{|c} 
Youths \\
$5-24$ \\
$(\mathrm{pp})$
\end{tabular} \\
\hline Total & 1586 & 0 & 29,4 & 22,7 & 53,4 & 15,4 & 741 & 0 & $-1,8$ & $-1,2$ & 0,8 & 3,1 \\
\hline $\begin{array}{l}\text { First } 3 \\
\text { countries of } \\
\text { destination }\end{array}$ & 1108 & 69,9 & 33,2 & 15,6 & 53,0 & 16,3 & 595 & 9,2 & $-1,3$ & $-1,2$ & $\mathbf{0 , 0}$ & 4,7 \\
\hline Germany & 492 & 31,1 & 29,9 & 18,6 & 54,9 & 10,9 & 104 & $-14,8$ & $-0,8$ & 0 & 1,2 & 1,9 \\
\hline Spain & 395 & 24,9 & 38,3 & 16,6 & 49,2 & 23,3 & 344 & 18,9 & -24 & 3,6 & 8,4 & 0,2 \\
\hline Italy & 221 & 13,9 & 31,3 & 6,9 & 55,7 & 15,8 & 147 & 5,1 & $-4,1$ & $-2,9$ & $-2,1$ & $-1,3$ \\
\hline
\end{tabular}

Source calculations based on Widmaier, S. and J-C. Dumont (2011), "Are recent immigrants different? A new profile of immigrants în the OECD based on DIOC 2005/06", OECD Social, Employment and Migration Working Papers No. 126, Directorate for Employment, Labour and Social Affairs, OECD Publishing, p. 53-55, http://dx.doi.org/10.1787/5kg3ml17nps4-en

Romania's economic growth in the period 2004-2008, otherwise a conjectural one, without a clear orientation of the fields of economic development and (as seen later on) unsustainable, associated with the structural deficit between the supply of the educational system (graduates) on fields and training levels and the demand of the business environment have stimulated external mobility.

Main shifts in migrant population flows for labour from Romania during the last years

A synthetic image of shifts in the model for Romanians' migration during the last years highlights both a significant quantitative change, and one of the main migration routes. 
Table no. 6.

Synthetic image of migration from Romania

\begin{tabular}{|l|l|l|}
\hline Emigration & $\mathbf{2 0 0 5}$ & $\mathbf{2 0 1 0}$ \\
\hline Stock of migrants (thousand persons) & 1244 & 2769 \\
\hline Migrants stock as percent in total population & 5,7 & 13,1 \\
\hline Top countries of destination & Israel & Italy \\
& Hungary & Spain \\
& USA & Hungary \\
& Spain & Israel \\
& Italy & USA \\
& Germany & Germany \\
& Canada & Canada \\
Skilled migrants & Austria & Austria \\
& France & France \\
Emigration rate for the population with tertiary & Grecia & Regatul Unit \\
education & 14,1 & 11,8 \\
\hline Physicians' migration & 5,1 & 6,9 \\
\hline \multicolumn{2}{|c|}{ Source: Migration and Remittances Factbook 2011, 2005, World Bank, } \\
\hline http://siteresources.worldbank.org/INTLAC/Resources/Factbook2011-Ebook.pdf
\end{tabular}

The first 5 countries of destination change their hierarchy in Romanians' preferences, Israel and USA present on the first positions in 2005 make place for Italy and Spain. The hierarchy is maintained for the positions 5 to 9 , and Greece on the $10^{\text {th }}$ position in 2005 is replaced by the United Kingdom. This change of destinations brings along also a change of the structure according to the educational level and profile, as the share of those with tertiary education decreases, yet increases as absolute number. Quantitatively, we lose more highly-skilled youths, some of them with specialisations with high deficit also in Romania (Boboc C, Vasile V., Ghita S, 2011).

The mobility of Romanian citizens abroad for labour was in the last decade more intense than in the past, partially supported by the bilateral programmes and agreements and subsequently by Romania's accession to the EU area, situation in which, temporary and for some countries were developed selective and gradual opening programmes of the national labour markets (the restriction period of up to 7 years defined by the agreements regarding mobility of citizens from the new member states within the EU area). It should be mentioned that for immigrants from outside the EU area, these additional restrictions do not appear, the general policy is applied in regulating the circulation of labour force (including by bilateral agreements). Consequently, the labour force of the new member states had circulation restrictions within the EU area more important than in the pre-accession period (!). It should also be mentioned that, at least in the case of Romania, the massive and unmonitored exodus forecasted for the period immediately after 1 January 2007 did not take place, and not due to movement barriers imposed by the old EU member states, but because the migration geography proved to be relatively independent from the punctual changes within the legislative and institutional framework related to labour force mobility. This finding is supported also by the statistics regarding naturalisation or definitive residence settlement in countries with significant immigration from within the EU. Migration management by policy measures at the level of the immigration countries and in relation to the migrant flows, on countries of origin, were the main adjustment or even geography redefining components for the Romanian migrants' in the post-accession period. According to the OECD data, Romania holds the 2 position in top 25 migration countries within the OECD area in the period 2000-2010, Poland taking the $4^{\text {th }}$ position, Bulgaria $15^{\text {th }}$, and Turkey the $23^{\text {rd }}$. The historical trend of the presence, preponderantly of immigrants from Europe to OECD countries is maintained and even a more marked increase takes 
place for those from Asia, especially due to migration from China (placed on the first position), and India ( $3^{\text {rd }}$ position). The place held by Romania is justified also based on the mobility from the period 2000-2005, of pre-accession when as shown the main factor of stimulating the flows' intensification was constituted by the bilateral agreements with some member countries, especially Spain and Italy.

Romania is registered with the highest dynamics in this period, yet the initial data for the year 2000 are lower than other statistical recordings done by the same organisation ( 88 thousand persons in 2000 - OECD 2012 against 1144.1 thousand persons of 15 years of age and over OECD-DIOC-E about 2000). Yet, the data seem to be more coherent for the year 2010, being correlated, in our opinion with the other databanks, respectively the databank of the World Bank which highlights a migrant population stock from Romania of 2769.4 thousand persons with a rate of $13.1 \%$ (2010), WB 2011.

Table no. 7.

Selection from Top 25 immigration countries within the OECD area 2000-2010

\begin{tabular}{|c|c|c|c|c|c|c|c|c|}
\hline \multirow[b]{2}{*}{$\begin{array}{l}\text { Area/country } \\
\text { (position in } \\
\text { hierarchy) }\end{array}$} & \multicolumn{4}{|c|}{ Thousand persons } & \multicolumn{4}{|c|}{2010} \\
\hline & 2000 & 2005 & 2009 & 2010 & $\begin{array}{c}\% \\
\text { in total } \\
\text { migrants }\end{array}$ & $\begin{array}{c}\% \\
2009\end{array}$ & $\begin{array}{c}\% \% \\
\text { change } \\
\text { against } \\
2000\end{array}$ & $\begin{array}{c}\text { Migration } \\
\text { rate to } 1000 \\
\text { persons } \\
\text { (population) }\end{array}$ \\
\hline China (1) & 282 & 438 & 450 & 508 & 9,5 & 11 & 80 & 0,4 \\
\hline Romania (2) & 88 & 212 & 276 & 289 & 5,5 & 5 & 229 & 13,0 \\
\hline India (3) & 113 & 212 & 227 & 252 & 4,8 & 11 & 123 & 0,2 \\
\hline Poland (4) & 104 & 264 & 220 & 223 & 4,2 & 1 & 114 & 5,6 \\
\hline $\operatorname{USA}(7)$ & 99 & 113 & 133 & 139 & 2,6 & 5 & 39 & 0,4 \\
\hline $\begin{array}{l}\text { United } \\
\text { Kingdom (9) }\end{array}$ & 95 & 157 & 129 & 118 & 2,2 & -9 & 24 & 1,8 \\
\hline Germany (10) & 71 & 98 & 126 & 117 & 2,2 & -7 & 64 & 1,4 \\
\hline France (12) & 70 & 68 & 93 & 91 & 1,7 & -2 & 29 & 1,4 \\
\hline Ukraine (14) & 57 & 105 & 79 & 81 & 1,5 & 2 & 42 & 1,7 \\
\hline Bulgaria (15) & 27 & 43 & 66 & 78 & 1,5 & 18 & 190 & 10,0 \\
\hline Italy (16) & 61 & 53 & 73 & 78 & 1,5 & 6 & 27 & 1,2 \\
\hline $\begin{array}{l}\text { Russian } \\
\text { Federation (20) }\end{array}$ & 84 & 86 & 66 & 68 & 1,3 & 2 & -19 & 0,5 \\
\hline Turkey 23 & 83 & 75 & 63 & 62 & 1,2 & -1 & -25 & 0,9 \\
\hline Europe & 1189 & 1609 & 1686 & 1759 & 33,3 & 4 & 48 & 2.3 \\
\hline Asia & 1159 & 1562 & 1677 & 1823 & 34,5 & 9 & 56 & 0,4 \\
\hline Americas & 809 & 979 & 970 & 925 & 17,5 & -5 & 14 & 1,0 \\
\hline Africa & 329 & 496 & 548 & 515 & 9,8 & -6 & 5,7 & 0,5 \\
\hline Oceania & 89 & 80 & 81 & 76 & 1,4 & -5 & -15 & 2.0 \\
\hline
\end{tabular}

Source: OECD 2012 - International Migration Outlook 2012, Part I, Table 1.8.

But, irrespective of these differences (partially justified by the definition and statistical registration system of "immigrants" in each country) it should be mentioned that the population loss in Romania for the last decade is rather worrying under the aspect of labour force reduction, which was not done by de-pressuring the labour market and unemployment diminishment, but by de-structuring national supply on professions and trades, labour migration having firstly earnings differential reasoning. It is a certainty that Romanian migrants represented in the year $2010,5.5 \%$ from total migrants in the OECD area, with a more tempered dynamic during the crisis, yet we can appreciate that the peak of the migrant wave was overcome and not just postponed by the crisis. 
If we take into account the total number of Romanians in the countries of destination, the most attractive countries and the most permissive for Romanian workers are Italy and Spain, each with about 813 , and respectively 810 thousand persons, followed at a large distance by Hungary with 189 thousand persons, Israel with 182 thousand persons, USA with 171 thousand persons, Germany with almost 135 thousand persons, and Canada with 96 thousand persons. In Austria, France and the United Kingdom there are about 53-57 thousand persons, and in Greece 45 thousand persons.

Table no. 8 .

Labour mobility matrix, Romania 2010

\begin{tabular}{|c|c|c|c|}
\hline Country & $\begin{array}{ll}\text { Left } & \text { from } \\
\text { Romania } & \end{array}$ & $\begin{array}{ll}\text { Arrived } & \text { to } \\
\text { Romania } & \end{array}$ & $\begin{array}{l}\text { Loss (-)/ gain }(+) \text { of persons for } \\
\text { Romania's labour market (persons) }\end{array}$ \\
\hline $\begin{array}{l}\text { TOTAL(persons) } \\
\text { From which, } \%\end{array}$ & 2769053 & 132757 & -2636296 \\
\hline EU 27 & 81,254 & 26,160 & -2215230 \\
\hline Italy & 29,362 & 1,894 & -810523 \\
\hline Spain & 29,269 & 0 & -810471 \\
\hline Hungary & 6,827 & 4,312 & -183331 \\
\hline Germany & 4,872 & 1,763 & -132571 \\
\hline Austria & 2,056 & 0 & -56932 \\
\hline France & 1,961 & 0 & -54305 \\
\hline United Kingdom & 1,917 & 0 & -53081 \\
\hline Greece & 1,636 & 3,314 & -40890 \\
\hline Belgium & 0,781 & 0 & -21634 \\
\hline Sweden & 0,584 & 0 & -16184 \\
\hline Ireland & 0,458 & 0 & -12682 \\
\hline Czech R. & 0,436 & 0 & -12083 \\
\hline Netherlands & 0,315 & 0 & -8716 \\
\hline Cyprus & 0,172 & 0 & -4774 \\
\hline Denmark & 0,151 & 0 & -4186 \\
\hline Portugal & 0,143 & 0 & -3954 \\
\hline Poland & 0,131 & 0 & -3632 \\
\hline Slovakia & 0,099 & 0 & -2751 \\
\hline Finland & 0,044 & 0 & -1210 \\
\hline Luxembourg & 0,025 & 0 & -683 \\
\hline Slovenia & 0,013 & 0 & -369 \\
\hline Lithuania & 0,001 & 0 & -20 \\
\hline Bulgaria & 0 & 14,878 & 19752 \\
\hline Rest of Europe & 1,199 & 3,295 & -28819 \\
\hline Switzerland & 0,286 & 0 & -7914 \\
\hline Norway & 0,074 & 0 & -2045 \\
\hline Turkey & 0,839 & 2,145 & -20384 \\
\hline $\begin{array}{ll}\text { Bosnia } & \text { and } \\
\text { Herzegovina } & \end{array}$ & 0,000 & 0 & -2 \\
\hline Croatia & & 1,149 & 1526 \\
\hline Other countries & $\mathbf{1 7 . 5 4}$ & $\mathbf{7 0 . 5 4 5}$ & -392247 \\
\hline Israel & 6,576 & 0 & -182099 \\
\hline USA & 6,185 & 1,092 & -169803 \\
\hline Canada & 3,474 & 0 & -96209 \\
\hline Australia & 0,630 & 0 & -17449 \\
\hline Japan & 0,096 & 0 & -2660 \\
\hline Moldova & 0 & 29,446 & 39091 \\
\hline
\end{tabular}




\begin{tabular}{|c|c|c|c|}
\hline Country & $\begin{array}{ll}\text { Left } & \text { from } \\
\text { Romania } & \\
\end{array}$ & \begin{tabular}{|ll} 
Arrived & to \\
Romania & \\
\end{tabular} & $\begin{array}{l}\text { Loss (-)/ gain }(+) \text { of persons for } \\
\text { Romania's labour market (persons) }\end{array}$ \\
\hline Ukraine & 0 & 10,463 & 13890 \\
\hline Russia & 0 & 5,845 & 7760 \\
\hline China & 0 & 1,610 & 2138 \\
\hline Brazil & 0,128 & 0 & -3548 \\
\hline New Zealand & 0,090 & 0 & -2497 \\
\hline Jordan & 0,081 & 0 & -2236 \\
\hline Venezuela & 0,024 & 0 & -675 \\
\hline Chile & 0,023 & 0 & -630 \\
\hline Georgia & 0,017 & 0 & -476 \\
\hline Uruguay & 0,015 & 0 & -424 \\
\hline Ecuador & 0,015 & 0 & -413 \\
\hline Mexico & 0,013 & 0 & -357 \\
\hline Philippines & 0,007 & 0 & -192 \\
\hline Peru & 0,006 & 0 & -179 \\
\hline Columbia & 0,006 & 0 & -179 \\
\hline Iceland & 0,006 & 0 & -171 \\
\hline Panama & 0,004 & 0 & $\begin{array}{l}-106 \\
\end{array}$ \\
\hline Bolivia & 0,002 & 0 & -67 \\
\hline Dominican R. & 0,002 & 0 & -45 \\
\hline Mauritania & 0,001 & 0 & -32 \\
\hline Bahamas & 0,001 & 0 & -23 \\
\hline Cayman Islands & 0,000 & 0 & -6 \\
\hline Syria & 0 & 5,533 & 7346 \\
\hline Libya & 0 & 0,767 & 1018 \\
\hline Iraq & 0 & 0,766 & 1017 \\
\hline Others south & 0,143 & 12,634 & 12799 \\
\hline Others north & 0 & 2,391 & 3174 \\
\hline
\end{tabular}

Note: Migrants 2010, Total world $=215763573$, Romania in total departed $=1,283 \%$; arrived $=0,062 \%$; Remittances 2010, Total world $=440077$, Romania in total entered remittances $=1,027$; exited $=0,039 \%$.

Source: WB 2011, Migration and remittances Factbook 2011, $2^{\text {nd }}$ edition, 2011 The International Bank for Reconstruction and Development / The World Bank,

http://econ.worldbank.org/WBSITE/EXTERNAL/EXTDEC/EXTDECPROSPECTS/

0,,contentMDK:22803131 pagePK:64165401 piPK:64165026 theSitePK:476883,00.html

It is worrying that the stock of Romanian workers abroad exceeds $27 \%$ of the total labour force of Romania (!). In the year 2010, migrants from Romania were present in the most significant immigration countries from Europe, such as Germany, Spain, France, United Kingdom and Italy, yet the shares are different. As total number, the most numerous are in Spain and Italy and the lowest presence is in the United Kingdom and France. A whole image of the migrants' situation in countries with a high share of foreign-born workers mobility on the labour market underpins this broad situations' diversity, defined by the specific attributes of the labour market segments that allow for their employment (next table).

Migration from Romania can be regarded as a pressure factor on the labour market in Hungary where it holds about 50\% from total migrants' labour market, yet it should be mentioned that in this country have migrated in majority Hungarian ethnics with family relationships and who speak the language of the country, hence their integration on the labour market was done under special conditions.

For Italy and Spain, the Romanians represent under $20 \%$ from total migrants, and are present on completion labour market segments (covering the deficits from agriculture and services), and knowledge of the national language is extremely easy due to linguistic similarities. 
Additionally, there are also in these instances significant cultural relationships that facilitate social integration, which favoured also building-up/strengthening social networks between Romania and these countries, as well as the development of some relatively stable communities of Romanians in some regions, as presented in the two case-studies.

Table no.9.

Characteristics of the Romanian's presence in EU countries (2010)

\begin{tabular}{|l|l|l|l|l|l|l|}
\hline $\begin{array}{c}\text { Country } \\
\text { (according to } \\
\text { the hierarchy of } \\
\text { the first EU } \\
\text { states as } \\
\text { destination for } \\
\text { Romania)(*) }\end{array}$ & $\begin{array}{c}\text { Total } \\
\text { number of } \\
\text { migrants } \\
\text { from EU } \\
\text { in } \boldsymbol{i} \\
\text { country } \\
\text { (millions }\end{array}$ & $\begin{array}{c}\text { Share of } \\
\text { migrants } \\
\text { from EU } \\
\text { countries in } \\
\text { total } \\
\text { migration of } \\
\text { the } \boldsymbol{i} \text { country } \\
(\boldsymbol{\%})\end{array}$ & $\begin{array}{c}\text { Persons in } \boldsymbol{i} \\
\text { country } \\
\text { living in } \\
\text { other } \\
\text { countries } \\
\text { from EU } \\
\text { (millions) }\end{array}$ & $\begin{array}{c}\text { Net } \\
\text { migration } \\
\text { stock } \\
\text { (entries- } \\
\text { exits) in } \boldsymbol{i} \\
\text { country }\end{array}$ & $\begin{array}{c}\text { Romanian } \\
\text { migrants } \\
\text { in total EU } \\
\text { migrants } \\
\text { in } \boldsymbol{i} \\
\text { country }\end{array}$ & $\begin{array}{c}\text { Romanian } \\
\text { migrants } \\
\text { in total } \\
\text { migrants } \\
\text { in } \boldsymbol{i} \\
\text { country }\end{array}$ \\
\hline Italy & 1,22 & 27,3 & 1,73 & $-0,51$ & 66,6 & 18.19 \\
\hline Spain & 2,51 & 36,4 & 0,73 & 1,78 & 32,29 & 11,75 \\
\hline Hungary & 0,25 & 67,7 & 0,25 & 0 & 75,62 & 51,20 \\
\hline Germany & 3,7 & 34,4 & 1,52 & 2,18 & 3,65 & 0,93 \\
\hline Austria & 0,55 & 41,9 & 0,38 & 0,17 & 10,35 & 4,34 \\
\hline France & 2,4 & 35,9 & 1,03 & 1,38 & 2,26 & 0,81 \\
\hline United Kingdom & 2,2 & 31,7 & 1,37 & 0,83 & 2,41 & 0,76 \\
\hline Greece & 0,21 & 18,6 & 0,6 & $-0,39$ & 21,57 & 4,01 \\
\hline
\end{tabular}

(*) in 2010 absorbtion of 77,89\% from total migrant stock of Romania (2157081 persons)

Source: based on data from www.migrationobservatory.ox.ac.uk and own calculations using the databank World Bank: Bilateral Migration and Remittances 2010 Excel datasets.

For Austria and Greece, Romanians' migration is under 5\% from total, and migrants from Romania to their vast majority know the language of the country or work in fields where is used an international language. The labour market restrictions limit the presence of Romanians and therefore we cannot appreciate that they exercise pressures and generate comparative disadvantages to natives on the local labour markets.

For Germany, France and the United Kingdom, migrant Romanians are less than $1 \%$, their integration on the labour market is difficult but does not generate economic pressures or social tensions. The issues emerging in these countries are related to the illegal immigration segment of certain ethnic groups from Romania (Rroma population, who by cultural profile and lifestyle have behavioural differences and a variety and volatility of their appurtenance to a group or community) and who do not make the object of the present study.

A minute account on countries of destination, where the number of migrants is between 100 persons (Panama) and over 810000 (Italy and Spain), indicates a low pressure exercised by the temporary migrants' presence on the labour markets from the countries of destination, if we analyse their share in total labour force (previous graph). After this last criterion, Romanians' migration represents fewer than $6 \%$ from the labour force in Israel, a bit over $4 \%$ in Hungary and about 3.2$3.5 \%$ in Italy and Spain. 


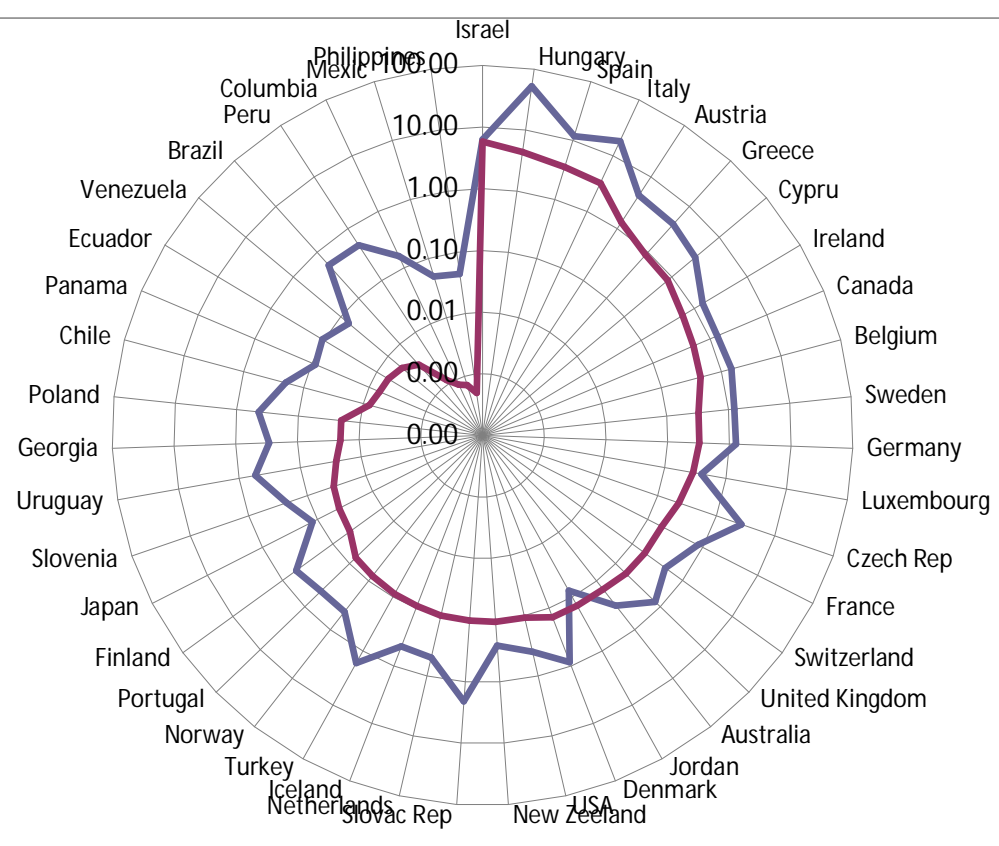

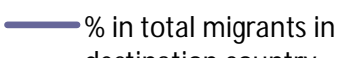
destination country

$\%$ in total labour force in destination country

\section{Graph no.2.- Distribution of migration from Romania and importance for the labour market on countries of destination (2010)}

Source: Processing based on Ratha and Shaw (2007) updated with additional data for 71 destination countries as described în the Migration and Remittances Factbook 2011, http://econ.worldbank.org/WBSITE/EXTERNAL /EXTDEC/EXTDECPROSPECTS/0,,contentMDK:22803131 pagePK:64165401 piPK:64165026 theSitePK:476883,00.html

Considering the numbers and shares of Romanian migrants on the labour markets in the countries of destination, is found that the first 5 positions in the cumulated score of the hierarchies are held, in order, by Hungary, Italy, Spain, Israel and Austria.

Table no. 10.

Importance of $\mathbf{t}$ Romanian migrans' presence on the labour markets in the destination countries (2010)

\begin{tabular}{|c|c|c|c|c|c|c|c|c|}
\hline Country & $\begin{array}{c}\text { Left from } \\
\text { Romania } \\
\text { (number } \\
\text { of } \\
\text { persons) }\end{array}$ & $\begin{array}{l}\text { Place in } \\
\text { hierarchy } \\
\text { after the } \\
\text { total } \\
\text { number of } \\
\text { Rumanian } \\
\text { migrants }\end{array}$ & $\begin{array}{c}\% \text { in } \\
\text { total } \\
\text { migrants } \\
\text { in the } \\
\text { country } \\
\text { of } \\
\text { destinatio } \\
n\end{array}$ & $\begin{array}{c}\text { Place in } \\
\text { hierarchy } \\
\text { after the } \\
\text { share of } \\
\text { Romanian } \\
\text { migrants in } \\
\text { total } \\
\text { migrants in } \\
\text { the country } \\
\text { of } \\
\text { destination }\end{array}$ & $\begin{array}{c}\% \\
\text { in total } \\
\text { labour } \\
\text { force in } \\
\text { the } \\
\text { country of } \\
\text { destination }\end{array}$ & $\begin{array}{l}\text { Place in the } \\
\text { hierarchy } \\
\text { after the } \\
\text { share of } \\
\text { Romanian } \\
\text { migrants in } \\
\text { total labour } \\
\text { force in the } \\
\text { country of } \\
\text { destination }\end{array}$ & $\begin{array}{l}\text { Cumulat } \\
\text { ed score } \\
\text { of the } \\
\text { hierarch } \\
\text { y after } \\
\text { the } 3 \\
\text { criteria }\end{array}$ & $\begin{array}{l}\text { Position in } \\
\text { hierarchy } \\
\text { after the } \\
\text { cumulated } \\
\text { score }\end{array}$ \\
\hline Italy & 813037 & 1 & 18,22 & 2 & 3,24 & 4 & 7 & 2 \\
\hline Spain & 810471 & 2 & 11,75 & 3 & 3,49 & 3 & 8 & 3 \\
\hline Hungary & 189055 & 3 & 51,36 & 1 & 4,38 & 2 & 6 & 1 \\
\hline Israel & 182099 & 4 & 6,19 & 4 & 5,73 & 1 & 9 & 4 \\
\hline USA & 171253 & 5 & 0,40 & 29 & 0,11 & 21 & 55 & 17 \\
\hline Germany & 134911 & 6 & 1,25 & 14 & 0,32 & 12 & 32 & 8 \\
\hline Canada & 96209 & 7 & 1,34 & 13 & 0,51 & 9 & 29 & 7 \\
\hline Austria & 56932 & 8 & 4,35 & 5 & 1,31 & 5 & 18 & 5 \\
\hline France & 54305 & 9 & 0,81 & 17 & 0,18 & 15 & 41 & 14 \\
\hline $\begin{array}{l}\text { United } \\
\text { Kingdom }\end{array}$ & 53081 & 10 & 0,76 & 18 & 0,17 & 17 & 45 & 15 \\
\hline Greece & 45289 & 11 & 4,00 & 6 & 0,86 & 6 & 23 & 6 \\
\hline
\end{tabular}




\begin{tabular}{|c|c|c|c|c|c|c|c|c|}
\hline Turkey & 23232 & 12 & 1,65 & 10 & 0,09 & 26 & 48 & 16 \\
\hline Belgium & 21634 & 13 & 1,48 & 11 & 0,44 & 10 & 34 & 10 \\
\hline Australia & 17449 & 14 & 0,32 & 31 & 0,15 & 18 & 63 & 21 \\
\hline Sweden & 16184 & 15 & 1,24 & 15 & 0,32 & 11 & 41 & 13 \\
\hline Ireland & 12682 & 16 & 1,41 & 12 & 0,60 & 8 & 36 & 11 \\
\hline Czech R. & 12083 & 17 & 2,67 & 8 & 0,23 & 14 & 39 & 12 \\
\hline $\begin{array}{l}\text { Netherland } \\
\mathrm{s}\end{array}$ & 8716 & 18 & 0,50 & 22 & 0,10 & 24 & 64 & 22 \\
\hline $\begin{array}{l}\text { Switzerlan } \\
\text { d }\end{array}$ & 7914 & 19 & 0,45 & 25 & 0,18 & 16 & 60 & 20 \\
\hline Cyprus & 4774 & 20 & 3,09 & 7 & 0,82 & 7 & 34 & 9 \\
\hline Denmark & 4186 & 21 & 0,87 & 16 & 0,14 & 20 & 57 & 18 \\
\hline Portugal & 3954 & 22 & 0,43 & 27 & 0,07 & 28 & 77 & 24 \\
\hline Poland & 3632 & 23 & 0,44 & 26 & 0,02 & 34 & 83 & 27 \\
\hline Brazil & 3548 & 24 & 0,52 & 21 & 0,00 & 40 & 85 & 29 \\
\hline Slovakia & 2751 & 25 & 2,11 & 9 & 0,10 & 23 & 57 & 19 \\
\hline Japan & 2660 & 26 & 0,12 & 37 & 0,04 & 30 & 93 & 33 \\
\hline $\begin{array}{l}\text { New } \\
\text { Zealand }\end{array}$ & 2497 & 27 & 0,26 & 33 & 0,11 & 22 & 82 & 26 \\
\hline Jordan & 2236 & 28 & 0,08 & 40 & 0,14 & 19 & 87 & 30 \\
\hline Norway & 2045 & 29 & 0,42 & 28 & 0,08 & 27 & 84 & 28 \\
\hline Finland & 1210 & 30 & 0,54 & 19 & 0,04 & 29 & 78 & 25 \\
\hline $\begin{array}{l}\text { Luxembour } \\
\mathrm{g}\end{array}$ & 683 & 31 & 0,39 & 30 & 0,29 & 13 & 74 & 23 \\
\hline Venezuela & 675 & 32 & 0,07 & 42 & 0,01 & 39 & 113 & 39 \\
\hline Chile & 630 & 33 & 0,20 & 35 & 0,01 & 36 & 104 & 36 \\
\hline Georgia & 476 & 34 & 0,28 & 32 & 0,02 & 33 & 99 & 34 \\
\hline Uruguay & 424 & 35 & 0,53 & 20 & 0,02 & 32 & 87 & 31 \\
\hline Ecuador & 413 & 36 & 0,10 & 38 & 0,01 & 38 & 112 & 38 \\
\hline Slovenia & 369 & 37 & 0,23 & 34 & 0,04 & 31 & 102 & 35 \\
\hline Mexico & 357 & 38 & 0,05 & 43 & 0,00 & 47 & 128 & 43 \\
\hline Philippines & 192 & 39 & 0,04 & 45 & 0,00 & 48 & 132 & 45 \\
\hline Peru & 179 & 40 & 0,48 & 23 & 0,00 & 44 & 107 & 37 \\
\hline Columbia & 179 & 41 & 0,16 & 36 & 0,00 & 46 & 123 & 42 \\
\hline Iceland & 171 & 42 & 0,46 & 24 & 0,09 & 25 & 91 & 32 \\
\hline Panama & 106 & 43 & 0,09 & 39 & 0,01 & 37 & 119 & 40 \\
\hline Bolivia & 67 & 44 & 0,05 & 44 & 0,00 & 42 & 130 & 44 \\
\hline $\begin{array}{l}\text { Dominican } \\
\text { Republic }\end{array}$ & 45 & 45 & 0,01 & 48 & 0,00 & 45 & 138 & 48 \\
\hline Mauritania & 32 & 46 & 0,03 & 46 & 0,00 & 41 & 133 & 46 \\
\hline Bahamas & 23 & 47 & 0,07 & 41 & 0,01 & 35 & 123 & 41 \\
\hline Lithuania & 20 & 48 & 0,02 & 47 & 0,00 & 43 & 138 & 47 \\
\hline $\begin{array}{l}\text { Bosnia and } \\
\text { Herzegovin } \\
\text { a }\end{array}$ & 2 & 49 & 0,01 & 49 & 0,00 & 49 & 147 & 49 \\
\hline
\end{tabular}

Source: Processing based on Ratha and Shaw (2007) updated with additional data for 71 destination countries as described in the Migration and Remittances Factbook 2011, http://econ.worldbank.org/WBSITE/EXTERNAL /EXTDEC/EXTDECPROSPECTS/0,,contentMDK:22803131 pagePK:64165401 piPK:64165026 theSitePK:476883,00.html

Nevertheless, according to mass-media, the greatest issues are created by Romanian migrants in France and Germany, where also the highest rejection is shown towards immigrants by the local communities. But, even in these cases, the issues are posed by certain groups that have an illegal presence and act on the black labour market, or don't work at all. The social pressures are 
generated by the illegal immigration and the social behaviours associated to some population categories permanently on the move, the labour market being affected to the extent in which the employers practice illegal employment and approve such categories of workers ( see also Boboc C, Vasile, V 2011b). In all these countries social networks were constituted, that support migration flows and, therefore, return migration estimated as outcome of the crisis did not occur to the expected shares being much lower.

\section{Conclusions}

Romanian migrants represented in 2010, 5.5\% from total migrant within the OECD area, with a more tempered dynamic during the crisis, yet we can appreciate that the peak of the migrant wave was overcome not only postponed by the crisis.

Romanian citizens' mobility abroad for labour was in the last decade more intense than in the past, partially supported by the bilateral programmes and agreement and subsequently by Romania's accession to the EU area;

- Labour mobility represented the main reason of mobility;

- The labour force categories at the two extremes migrated: the highly-skilled and those in the category of the low-skilled or unskilled (in agriculture, in Spain), yet the differentiation on trades and professions and the accepted qualification level was imposed by the demand of the destination market (bilateral agreements, movement restrictions during a period of up to 7 years after accession);

- Migration was in particular recorded from among those working in fields such as education and health and who already were employed, which increased the structural deficits on the national labour market;

- Romanians' labour mobility exercises a low pressure on the labour markets in the countries of destination if we analyse their share in total labour force.

Another worrying aspect of temporary labour migration is that of the average duration of mobility stay. Working abroad brings along financial advantages because it is accompanied by remittances, yet the more the period of mobility expands, the more is the risk of permanent stay and hence net losses - of human capital, of household move, suspension or drastic diminishment of remittances flows', elimination of the return and re-employment possibility, with sustainable advantages for the labour market and business environment in the host country and definitive negative externalities for the labour market and the business environment in the country of origin (if not associated with bilateral commercial cooperation or business). Still, if return occurs, but not accompanied by re-employment or entrepreneurship but only by consumption and eventually by social services (pensions), then on long term incomes become flat and do not stimulate growth. In some instances, the poverty risk emerges again along with the dependency on social assistance. The comparative analysis of the average stay period of immigrants in the country of destination highlights the fact that the potential economic advantages resulting from mobility diminish substantially as the stay is expanded, and the advantages at national level in the country of origin are strongly limited or turn adverse.

Considering the cumulated effect of the Romanians' labour mobility, even if the estimates of the experts are based on the win-win principle, we can appreciate that Romania registered up to the present a net loss in material-financial terms, difficult to be quantified under all its aspects. The sustainable advantages are still expected and we appreciate that they will be felt on medium- and long-term.

\section{Acknowlegment}

This paper is supported by the Sectorial Operational Programme Human Resources Development (SOP HRD) 2007-2013, financed from the European Social Fund and by the Romanian Government under the contract number SOP HRD/89/1.5/s/61755, Project "SPODE". 


\section{References:}

1. Boboc C, Vasile V., Ghita S, 2011. Migration of physicians: causes and effects in CEE countries, Education and Management: International Symposium, ISAEBD 2011, Dalian, China, August 2011, Proceedings, Part.III, pp. 514-521, Communications in Computer and Information $\quad$ Science available online at http://link.springer.com/chapter/10.1007\%2F978-3-642-23065-3_74?LI=true

2. Boboc C., Vasile V., 2011b. Working with versus working without employment contract what differences in individuals wealth, education and unemployment risk, in ICASS 2012, 2nd International Conference on Applied Social Science, volume 2, Information Engineering Research Institute, USA, Edited by Jun Hu, February 1-2, Kuala Lumpur, Malaysia, pp. 358-364

3. Widmaier S., Dumont J.-C., 2011. Are recent immigrants different? A new profile of immigrants in the OECD based on DIOC 2005/06, OECD Social, Employment and Migration Working Papers No. 126, Directorate for Employment, Labour and Social Affairs, OECD Publishing, available online at http://dx.doi.org/10.1787/5kg3ml17nps4-en

4. Vasile V., Vasile L., 2011. Youth Labour Market. Mobility, Career Development, Incomes. Challenges And Opportunities, Annals of Faculty of Economics, University of Oradea, vol. 1(special), pages 251-263, July, available online at http://anale.steconomiceuoradea.ro/volume/2011/special/020.pdf

5. *** OECD, 2008. A profile of immigrant populations in the 21-st century: Data from OECD countries

6. *** OECD, 2012. International Migration Outlook 2012, available online at www.oecd.org/migration/imo

7. *** World Bank, 2011. Migration and remittances Factbook 2011, $2^{\text {nd }}$ edition, The International Bank for Reconstruction and Development / The World Bank, aaavailable online at http://siteresources.worldbank.org/INTLAC/Resources/Factbook2011Ebook.pdf 